\title{
Flow cytometry measurements of ploidy level in British Hieracium section Foliosa and section Prenanthoidea (Asteraceae)
}

\author{
Pavel Zdvořák ${ }^{1}$, Patrik Mráz ${ }^{1}$, Timothy C.G. Rich ${ }^{2 *}$ \\ ${ }^{1}$ Charles University, Praha 2, Czechia; ${ }^{2}$ Cardiff, U.K.
}

*Corresponding author: Timothy C.G. Rich: tim rich@sky.com

This pdf constitutes the Version of Record published on $30^{\text {th }}$ June 2020

\begin{abstract}
Ploidy level has been estimated in all extant British members of Hieracium section Foliosa (Fr.) Arv.-Touv. and section Prenanthoidea W. D. J. Koch (Asteraceae) from seed samples using flow cytometry. Hieracium bakerianum, $H$. drummondii, $H$. latobrigorum, $H$. maritimum, $H$. melanoglochin, $H$. reayense, $H$. reticulatiforme, $H$. strictiforme, $H$. subcrocatum, $H$. subumbellatiforme, $H$. tavense and $H$. prenanthoides were all triploid.
\end{abstract}

Keywords: chromosome count; triploid.

\section{Introduction}

As work towards a revision of British Hieracium section Foliosa (Fr.) Arv.-Touv. and section Prenanthoidea W. D. J. Koch (Asteraceae) by T.C.G. Rich, we have collected seeds of all extant members of the two sections and determined the ploidy level using flow cytometry. The ploidy results are briefly summarised below; further details and analysis will be published elsewhere (Mráz et al., in prep.).

\section{Methods}

Seeds were collected by T.C.G. Rich, Ian Green or Linda Robinson from plants in the wild in Britain in 2019, or in a few cases from material cultivated in Cardiff by T. Rich. Vouchers were verified by D. McCosh and are deposited in PRC or herb. T. Rich.

The flow cytometry method is set out in full in Mráz \& Zdvořák (2019) and is briefly summarised below. Batches of five Hieracium seeds were co-chopped with leaves of Bellis perennis as an internal standard. 4',6-diamino-2-phenylindole (DAPI) was used as a fluorescent stain. A Partec Cyflow instrument equipped with a HBO lamp was used for ploidy level analysis. Histograms were accumulated at a flow rate of $c .10-30$ particles s $\mathrm{s}^{-1}$ for a total count of 3000-6000 particles. The ploidy level of embryos was inferred as the relative position of the sample G1 peaks (corresponding to embryos) relative to that of the G1 peak of Bellis internal standard, which had previously been calibrated against Hieracium plants of known ploidy level. The coefficients of variation of fluorescent intensities (=peaks) of measured samples varied between $1.09 \%$ and $6.14 \%$, with a mean of $3.29 \%$, and those of internal standard varied between $1.57 \%$ and $4.66 \%$, with a mean of $3.2 \%$. Between 5 and 
45 seeds of each species were analysed (Table 1), i.e. from one to nine analyses were done per accession. Because of obligate sexuality in diploids, obligate or almost obligate apomixis in polyploids, and extremely rare incidence of between-ploidy gene flow, the ploidy of maternal plant can be easily deduced from the ploidy of seed progeny it produces (Mráz \& Zdvořák, 2019).

\section{Results}

The estimated ploidy levels of 11 species of section Foliosa and one species of section Prenanthoidea are shown in Table 1; all ploidy levels were found to be triploid.

\section{Discussion}

These are the first estimates of ploidy level for nine of the section Foliosa species in Britain. The only previous two chromosome counts for the section Foliosa are $2 n=27$ (3x triploid) for H. subcrocatum from Clova (v.c.90) (Morton, 1974) and an unlocalised British count of $2 n=27$ ( $3 x$ triploid) by R. A. Finch for $H$. latobrigorum (Moore, 1982). In addition, Tyler \& Jönsson (2009) using flow cytometry ascertained a triploid level for one section Foliosa accession from Scandinavia. Our estimates of ploidy level are thus in agreement with these previous counts / flow cytometric estimates.

There are no previous estimates of ploidy level for $H$. prenanthoides s.l. from Britain, and the four populations estimated are all triploid. There are many counts for $H$. prenanthoides s.I. from Europe; diploids $(2 n=18)$ occur solely in the SW Alps in France and Italy and they belong to H. prenanthoides Vill. (s.str.), whereas triploids $(2 n=27)$ are widespread in Europe and the Carpathians, and tetraploids $(2 n=36)$ have been recorded from Central Europe and Iceland (Chrtek et al., 2004, 2007, 2020; Ilnicki \& Szeląg, 2011; Kocián, 2013; Mráz \& Zdvořák 2019). The British triploids thus belong to the most widespread cytotype.

\section{Acknowledgements}

We thank Ian Green and Linda Robinson for collecting seed samples, David McCosh for checking the identifications, and Viera Mrázová for preparation of samples for flow cytometry.

Seed collecting was partly funded with a BSBI Science \& Research Committee Grant awarded to Tim Rich. The flow cytometry was funded by the Grant Agency of the Czech Republic as part of a wider Hieracium project (GAČR 17-14620S to PM). 
Table 1. Ploidy levels in extant British members of Hieracium section Foliosa and section Prenanthoidea. Nomenclature follows Sell \& Murrell (2006). The number after slash is the relative position (averaged value if several samples per accessions were run) of the G1 peak of endosperm relative to the G1 peak of the internal standard Bellis perennis.

\begin{tabular}{|c|c|c|c|c|}
\hline Species & Locality & $\begin{array}{l}\text { Ploidy/mean } \\
\text { (embryo/standard) }\end{array}$ & $\begin{array}{l}\text { No. } \\
\text { seeds } \\
\text { analysed }\end{array}$ & $\begin{array}{l}\text { T.C.G. } \\
\text { Rich's } \\
\text { collecting } \\
\text { number }\end{array}$ \\
\hline H. bakerianum Pugsley & $\begin{array}{l}\text { above High Force } \\
\text { (v.c.65) }\end{array}$ & $3 x / 3.24$ & 5 & 2019-169 \\
\hline H. drummondii Pugsley & Crinan (v.c. 101) & $3 \times / 3.24$ & 20 & $2019-106$ \\
\hline $\begin{array}{l}\text { H. latobrigorum (Zahn) } \\
\text { Roffey }\end{array}$ & $\begin{array}{l}\text { Ormsary Water } \\
\text { (v.c.101) }\end{array}$ & $3 x / 3.21$ & 20 & $2019-105$ \\
\hline $\begin{array}{l}\text { H. latobrigorum (Zahn) } \\
\text { Roffey }\end{array}$ & Grandtully (v.c.88) & $3 x / 3.27$ & 20 & $2019-116$ \\
\hline $\begin{array}{l}\text { H. maritimum (F. } \\
\text { Hanb.) F. Hanb. }\end{array}$ & Melvich (v.c.109) & $3 x / 3.31$ & 45 & $2019-061$ \\
\hline $\begin{array}{l}\text { H. maritimum (F. } \\
\text { Hanb.) F. Hanb. }\end{array}$ & Crear Burn (v.c.101) & $3 x / 3.36$ & 25 & $2019-102$ \\
\hline $\begin{array}{l}\text { H. melanoglochin (E.F. } \\
\text { Linton) P.D. Sell }\end{array}$ & $\begin{array}{l}\text { Acharn, Killin } \\
\text { (v.c.88) }\end{array}$ & $3 x / 3.21$ & 20 & 2019-109 \\
\hline $\begin{array}{l}\text { H. reayense (Pugsley) } \\
\text { P.D. Sell }\end{array}$ & Invervar (v.c.88) & $3 x / 3.24$ & 20 & $2019-113$ \\
\hline $\begin{array}{l}\text { H. reayense (Pugsley) } \\
\text { P.D. Sell }\end{array}$ & $\begin{array}{l}\text { Sandside, Reay } \\
\text { (v.c.109) }\end{array}$ & $3 x / 3.27$ & 20 & $2019-137$ \\
\hline $\begin{array}{l}\text { H. reticulatiforme P.D. } \\
\text { Sell }\end{array}$ & Nant y Llyn (v.c.42) & $3 x / 3.15$ & 20 & 2019-099 \\
\hline $\begin{array}{l}\text { H. strictiforme (Zahn) } \\
\text { Roffey }\end{array}$ & $\begin{array}{l}\text { Loch Sgioport } \\
\text { (v.c.101) }\end{array}$ & $3 x / 3.25$ & 30 & $2019-172$ \\
\hline $\begin{array}{l}\text { H. strictiforme (Zahn) } \\
\text { Roffey }\end{array}$ & $\begin{array}{l}\text { Glenernie, Divie } \\
\text { (v.c.95) }\end{array}$ & $3 x / 3.27$ & 20 & 2019-130 \\
\hline $\begin{array}{l}\text { H. subcrocatum (E.F. } \\
\text { Linton) Roffey }\end{array}$ & Cwm-porth (v.c.42) & $3 x / 3.15$ & 20 & 2019-067 \\
\hline $\begin{array}{l}\text { H. subcrocatum (E.F. } \\
\text { Linton) Roffey }\end{array}$ & $\begin{array}{l}\text { Glenernie, A940 } \\
\text { (v.c.95) }\end{array}$ & $3 x / 3.27$ & 20 & $2019-131$ \\
\hline $\begin{array}{l}\text { H. subumbellatiforme } \\
\text { (Zahn) Roffey }\end{array}$ & $\begin{array}{l}\text { Boat of Garten } \\
\text { (v.c.95) }\end{array}$ & $3 x / 3.27$ & 20 & 2019-129 \\
\hline $\begin{array}{l}\text { H. subumbellatiforme } \\
\text { (Zahn) Roffey }\end{array}$ & $\begin{array}{l}\text { Dowally, Roar } \\
\text { (v.c.89) }\end{array}$ & $3 x / 3.29$ & 20 & 2019-159 \\
\hline H. tavense (Ley) Ley & Nant-y-Llyn (v.c.42) & $3 x / 3.27$ & 10 & $2019-160$ \\
\hline $\begin{array}{l}\text { H. prenanthoides Vill. } \\
\text { s.l. }\end{array}$ & $\begin{array}{l}\text { Tarren-yr-Esgob } \\
\text { (v.c.42) }\end{array}$ & $3 x / 2.97$ & 20 & $2019-064$ \\
\hline $\begin{array}{l}\text { H. prenanthoides Vill. } \\
\text { s.l. }\end{array}$ & Braemar (v.c.92) & $3 x / 3.01$ & 10 & 2019-065 \\
\hline $\begin{array}{l}\text { H. prenanthoides Vill. } \\
\text { s.l. }\end{array}$ & Invervar (v.c.88) & $3 x / 3.06$ & 5 & 2019-112 \\
\hline $\begin{array}{l}\text { H. prenanthoides Vill. } \\
\text { s.l. }\end{array}$ & $\begin{array}{l}\text { Auchallater, } \\
\text { Braemar (v.c.92) }\end{array}$ & $3 x / 3.09$ & 20 & $2019-123$ \\
\hline
\end{tabular}




\section{References}

Chrtek, J. jun., Mráz, P. \& Severa, M. 2004. Chromosome numbers in selected species of Hieracium s. str. (Hieracium subgen. Hieracium) in the Western Carpathians. Preslia, Praha 76: 119-139.

Chrtek, J., Mráz, P., Belyayev, A., Paštová, L., Mrázová, V., Caklová, P., Josefiová, J., Zagorski, D., Hartmann, M., Jandová, M., Pinc, J. \& Fehrer, J. 2020. Evolutionary history and genetic diversity of apomictic allopolyploids in Hieracium s.str.: morphological versus genomic features. American Journal of Botany 107: 66-90.

Chrtek, J., Mráz, P., Zahradníček, J., Mateo Sanz, G. \& Szeląg, Z. 2007. Chromosome numbers and DNA ploidy levels of selected species of Hieracium s.str. (Asteraceae). Folia Geobotanica 42: 411-430.

Ilnicki, T. \& Szeląg, Z. 2011. Chromosome numbers in Hieracium and Pilosella (Asteraceae) from Central and South-eastern Europe. Acta Biologica Cracoviensia, Series Botanica 53: 102-110.

Kocián, J. 2013. Reproduction systems of the Hieracium prenanthoides polyploid complex. MSc thesis, Department of Botany, Faculty of Science, Palacký University in Olomouc.

Moore, D.M. 1982. Flora Europaea. Check-list and chromosome index. Cambridge: Cambridge University Press.

Morton, J.K. 1974. Chromosome numbers of British plants, 3. Watsonia 10: 169.

Mráz, P. \& Zdvořák, P. 2019. Reproductive pathways in Hieracium s.s. (Asteraceae): strict sexuality in diploids and apomixis in polyploids. Annals of Botany 123: 391-403.

Sell, P. D. \& Murrell, G. 2006. Flora of Great Britain and Ireland, Volume 4. Cambridge: Cambridge University Press.

Tyler, T. \& Jönsson, J. 2009. Ploidy level analysis of apomictic Hieracium (Asteraceae) reveal unexpected patterns and variation. Nordic Journal of Botany 27: 490-502.

Copyright retained by author(s). Published by BSBI under the terms of the Creative Commons Attribution 4.0 International Public License.

ISSN: $2632-4970$

https://doi.org/10.33928/bib.2020.02.154 